\title{
Hubbard Brook
}




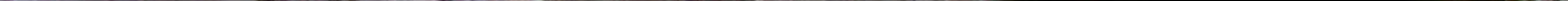


RICHARD T. HOLMES AND GENE E. LIKENS

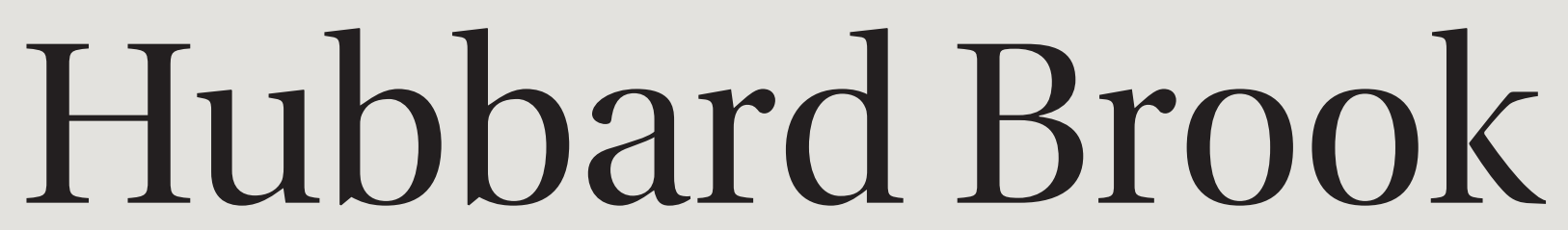

THE STORY OF A FOREST ECOSYSTEM

\section{Yale UNIVERSITY PRESS}


Frontispiece: The Gorge on the mainstem of Hubbard Brook (Photo by N. L. Cleavitt)

Published with assistance from the Mary Cady Tew Memorial Fund, and from the President's Office of Dartmouth College, with special thanks to Carol L. Folt, and from Furthermore: a program of the J. M. Kaplan Fund.

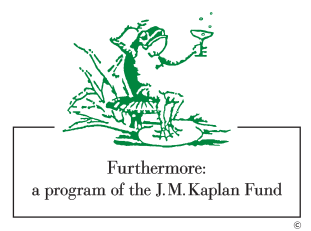

Copyright $\odot 2016$ by Richard T. Holmes and Gene E. Likens.

All rights reserved.

This book may not be reproduced, in whole or in part, including illustrations, in any form (beyond that copying permitted by Sections 107 and 108 of the U.S. Copyright Law and except by reviewers for the public press), without written permission from the publishers.
Yale University Press books may be purchased in quantity for educational, business, or promotional use. For information, please e-mail sales.press@yale.edu (U.S. office) or sales@yaleup.co.uk (U.K. office).

Designed by Richard Hendel

Set in Utopia and Aller type by Tseng Information Systems, Inc. Printed in China.

ISBN 978-0-300-20364-6 (cloth : alk. paper)

Library of Congress Control Number: 2015948837

A catalogue record for this book is available from the British Library. This paper meets the requirements of ANSI/NISO Z39.48-1992 (Permanence of Paper).

10987654321 